\title{
Economic Evaluation of Kinnow Mandarin Cultivation Using Inorganic and Organic Nutrient Sources Along with Biofertilizers
}

\author{
Manish Bakshi ${ }^{*}$, V.K. Wali ${ }^{2}$, Akash Sharma ${ }^{2}$ and Vishal Raina ${ }^{3}$ \\ ${ }^{I}$ Domain of Horticulture, School of Agriculture, Lovely Professional University, Punjab, India \\ ${ }^{2}$ Division of Fruit Science, SKUAST-J, India \\ ${ }^{3}$ Junior Agriculture Extension Officer, DoA, J\&K, India \\ *Corresponding author
}

\section{A B S T R A C T}

\begin{tabular}{|l|}
\hline K e y w o r d s \\
Kinnow mandarin, \\
Economics, INM, \\
Cost: benefit ratio, \\
Azotobacter
\end{tabular}

\section{Introduction}

The changing paradigm towards agriculture has necessitated that horticultural sector may be looked as an enterprise for providing the livelihood security to the farmers globally. Diversification in cultivation of horticultural crops will not only ensure sustained income to the farmer but will also generate the employment in the rural as well as urban sectors. India has a unique climatic advantage that makes it the world's second largest
A study aimed at evaluating the economics of cultivation of Kinnow mandarin (Citrus nobilis $\mathrm{x}$ Citrus deliciosa) using different integrated nutrient management treatments. Three organic manures (FYM, poultry manure and vermicompost) under three different experiments were used along with inorganic fertilizers and Azotobacter. Total cost of cultivation was maximum ( $₹ 98905.00)$ with the application of cent per cent application of nitrogen as vermicompost augmented with Azotobacter. The net returns on investment were highest (₹ 186968.00) under treatment where plants were applied with 25 per cent nitrogen as vermicompost and 75 per cent nitrogen as urea augmented with Azotobacter. Maximum benefit cost ratio of (1:3.28) was obtained under treatment comprising 50 per cent nitrogen as poultry manure and 50 per cent nitrogen as urea augmented with Azotobacter. A comparison between the three integrated nutrient management experiments in Kinnow mandarin revealed that maximum returns on investments can be achieved when half of the recommended dose of nitrogen through inorganic fertilizers is replaced with organic source (vermicompost) along with the application of biofertilizer. 
99.62 per cent of the total area in J\&K, whereas its production has been realized to be 0.019 MT, which is 99.96 per cent of the total production of J\&K (Anonymous, 2009). Among the citrus fruits, kinnow fruit cultivation in Jammu is gaining momentum among the fruit growers due to its profitability and good market value. Research has revealed that it responds well to integrated nutrient management strategies (Bakshi et al., 2017). Kinnow orchards start giving economic returns from the fifth year and remain economically productive up to 28 years, unlike Nagpur (oranges) mandarins, which give economic returns up to 30 years (Gupta and George, 1974). Apart from promoting the integrated nutrient management system in Kinnow mandarin, there is a need conduct an analysis on the economics of cultivation too. Therefore, a study was undertaken to evaluate the same under the subtropical conditions of Jammu in the state of Jammu and Kashmir.

\section{Materials and Methods}

The present studies were carried out at Research farm of Division of Fruit Science, Faculty of Agriculture, Sher-e-Kashmir University of Agricultural Sciences and Technology, Udheywalla, Jammu on six year old Kinnow mandarin trees, having uniform size and vigour. The study was conducted under three experiments using three different types of organic manures (FYM, poultry manure and vermicompost). Only one organic manure with different INM combinations was used per experiment. The basic treatment combinations were $\mathrm{T}_{1}(100 \% \mathrm{~N}$ as urea $), \mathrm{T}_{2}$ $(25 \% \mathrm{~N}$ as organic manure and $75 \% \mathrm{~N}$ as urea), $\mathrm{T}_{3}(50 \% \mathrm{~N}$ as organic manure and $50 \%$ $\mathrm{N}$ as urea), $\mathrm{T}_{4}(75 \% \mathrm{~N}$ as organic manure and $25 \% \mathrm{~N}$ as urea), $\mathrm{T}_{5}$ (Azotobacter $\left.+\mathrm{T}_{1}\right), \mathrm{T}_{6}$ $\left(\right.$ Azotobacter $\left.+\mathrm{T}_{2}\right), \mathrm{T}_{7}$ (Azotobacter $\left.+\mathrm{T}_{3}\right), \mathrm{T}_{8}$ $\left(\right.$ Azotobacter $\left.+\mathrm{T}_{4}\right), \mathrm{T}_{9}$ (Azotobacter $+100 \%$ $\mathrm{N}$ as organic manure), $\mathrm{T}_{10}(100 \% \mathrm{~N}$ as organic manure), $\mathrm{T}_{11}$ (Azotobacer application only) and $\mathrm{T}_{12}$ (control). Azotobacter culture was applied near active root zone @ $100 \mathrm{~g} \mathrm{tree}^{-1}$. All the treatments were evaluated for analysis of cost and returns and the data was calculated per hectare. The common cost concepts of agricultural economics are used to interpret the results. The various inputs used in the cultivation of Kinnow mandarin were divided into two components i.e. variable and fixed costs. There costs were worked out for different treatments separately. Variable costs include labour cost, cost of fertilizers and farm yard manure (FYM). Fixed cost includes rent paid on leased out land and interest paid on working capital. Gross returns were obtained by multiplying total production per ha per treatment with the prevailing wholesale price of Kinnow mandarin. Net returns were arrived at subtracting total cost of cultivation from gross returns. Likewise, cost: benefit ratio was calculated by dividing net returns by total cost of cultivation.

\section{Results and Discussion}

\section{Economics of INM using FYM, inorganic fertilizers and biofertilizer}

Effect of various treatments using inorganic fertilizers, farm yard manure and azotobacter on cost benefit ratio of Kinnow cultivation is presented in Table 1. Cent per cent application of nitrogen as FYM augmented with Azotobacter $\left(\mathrm{T}_{9}\right)$ recorded maximum total cost of cultivation (₹72,410.00) followed by treatment $\mathrm{T}_{8}$ (₹68,315.00). Lowest cost of cultivation (₹36,019.00) was recorded under control $\left(\mathrm{T}_{12}\right)$. Net returns on Kinnow crop were highest ( $₹ 1,82,188.00)$ under treatment where plants were applied with 25 per cent nitrogen as FYM and 75 per cent nitrogen as urea augmented with Azotobacter $\left(\mathrm{T}_{6}\right)$ followed by net returns of ₹ $1,56,895.00$ obtained under treatment $\mathrm{T}_{5}$ (application of cent per cent nitrogen as urea augmented with Azotobacter). Lowest net returns (₹43,185.00) 
were obtained under control. Highest total cost of cultivation was observed with the application was worked out under treatment $\mathrm{T}_{9}$ followed by application of 25 per cent nitrogen as urea +75 per cent nitrogen as farmyard manure augmented with Azotobacter. Net returns were highest with the application of 25 per cent nitrogen as farmyard manure +75 per cent nitrogen as urea augmented with Azotobacter. Maximum benefit cost ratio of (3.06) was obtained under treatment comprising 25 per cent nitrogen as FYM and 75 per cent nitrogen as urea augmented with Azotobacter $\left(\mathrm{T}_{6}\right)$ followed by cost benefit ratio of $1: 2.86$ and 1: 2.85 obtained under treatment $\mathrm{T}_{1}$ (cent per cent nitrogen as urea) and $\mathrm{T}_{5}$ (cent per cent nitrogen as urea augmented with Azotobacter). Lowest benefit cost ratio of 1: 0.65 was obtained under absolute control $\left(\mathrm{T}_{12}\right)$.

\section{Economics of INM using poultry manure, inorganic fertilizers and biofertilizer}

Table 2 reveals the effect of various treatments on economics of cultivation in Kinnow mandarin. Treatment comprising of cent per cent application of nitrogen as poultry manure augmented with Azotobacter $\left(\mathrm{T}_{9}\right)$ recorded maximum total cost of cultivation ( $₹$ $57,720.00$ ) followed by $₹ 57,053.00$ obtained under treatment $\mathrm{T}_{8}$. Lowest cost of cultivation (₹ 36,019.00) was recorded under control $\left(\mathrm{T}_{12}\right)$. The data further reveals that net returns were highest ( $₹ 1,85,154.00$ ) under the treatment where plants were applied with 50 per cent nitrogen as poultry manure and 50 per cent nitrogen as urea augmented with Azotobacter $\left(\mathrm{T}_{7}\right)$ followed by net returns of $₹$ $1,82,185.00$ obtained under treatment $\mathrm{T}_{6}$ (application of 25 cent per cent nitrogen as poultry manure and 75 per cent nitrogen as urea augmented with Azotobacter). Lowest net returns (₹ 42,616.00) were obtained under control. Maximum benefit cost ratio of (3.28) was obtained under treatment comprising 50 per cent nitrogen as poultry manure and 50 per cent nitrogen as urea augmented with Azotobacter $\left(\mathrm{T}_{7}\right)$ followed by benefit cost ratio of 1: 3.27 and 1: 3.01 obtained under treatment $\mathrm{T}_{6}$ and $\mathrm{T}_{5}$, respectively. Lowest benefit cost ratio of 1:1.15 was obtained under treatment comprising of Azotobacter alone $\left(\mathrm{T}_{11}\right)$. Maximum total cost of cultivation was observed with the application of cent per cent nitrogen as poultry manure augmented with Azotobacter followed by application of 25 per cent nitrogen as urea +75 per cent nitrogen as poultry manure augmented with Azotobacter.

Net returns were highest with the application of 50 per cent nitrogen as poultry manure +50 per cent nitrogen as urea augmented with Azotobacter. Maximum benefit: cost ratio was obtained with the application of 50 per cent nitrogen as poultry manure +50 per cent nitrogen as urea augmented with Azotobacter.

Economics of INM using vermicompost, inorganic fertilizers and biofertilizer

Effect of various treatments on cost benefit ratio of Kinnow cultivation is presented in Table 3. Treatment comprising of cent per cent application of nitrogen as vermicompost augmented with Azotobacter $\left(\mathrm{T}_{9}\right)$ recorded maximum total cost of cultivation (₹ 98,905.00) followed by ₹ 89,908.00 obtained under treatment comprising of application of cent per cent nitrogen as vermicompost $\left(\mathrm{T}_{10}\right)$. Lowest cost of cultivation ( $₹ 36,019.00$ ) was recorded under control $\left(\mathrm{T}_{12}\right)$. The table further revealed that net returns were highest ( $₹$ $1,86,968.00)$ under treatment where plants were applied with 25 per cent nitrogen as vermicompost and 75 per cent nitrogen as urea augmented with Azotobacter $\left(\mathrm{T}_{6}\right)$ followed by net returns of ₹ $1,65,545.00$ obtained under treatment $\mathrm{T}_{5}$ (application of cent per cent nitrogen as urea augmented with Azotobacter). 
Table.1 Effect of urea, FYM alone and in combination with Azotobacter on benefit cost ratio of kinnow mandarin cultivation

\begin{tabular}{|c|c|c|c|c|c|c|c|c|c|c|c|c|}
\hline Items of cost & $\mathbf{T}_{1}$ & $\mathbf{T}_{2}$ & $\mathbf{T}_{\mathbf{3}}$ & $\mathbf{T}_{4}$ & $\mathbf{T}_{5}$ & $\mathbf{T}_{6}$ & $\mathbf{T}_{7}$ & $\mathbf{T}_{8}$ & $\mathbf{T}_{9}$ & $\mathbf{T}_{10}$ & $\mathbf{T}_{11}$ & $\mathbf{T}_{12}$ \\
\hline Variable Cost & \multicolumn{12}{|c|}{ Amount (₹) } \\
\hline Labour & 24930 & 24930 & 24930 & 24930 & 27700 & 27700 & 27700 & 27700 & 27700 & 27700 & 24930 & 22160 \\
\hline $\begin{array}{l}\text { Cost of fertilizer } \\
\text { and manure }\end{array}$ & 3462.5 & 7395.9 & 11330 & 15262.7 & 11495.5 & 15428.9 & 19362.3 & 23295.7 & 26952.1 & 18919.1 & 9833.5 & 0 \\
\hline $\begin{array}{l}\text { Interest on } \\
\text { working capital @ } \\
12 \%\end{array}$ & 3407 & 3879 & 4351 & 4823 & 4703 & 5175 & 5647 & 6119 & 6558 & 5594 & 4172 & 2659 \\
\hline Total variable cost & 31800 & 36205 & 40611 & 45016 & 43899 & 48304 & 52710 & 57115 & 61210 & 52213 & 38935 & 24819 \\
\hline \multicolumn{13}{|l|}{ Fixed Cost } \\
\hline $\begin{array}{l}\text { Rent paid for } \\
\text { leased in land }\end{array}$ & 10000 & 10000 & 10000 & 10000 & 10000 & 10000 & 10000 & 10000 & 10000 & 10000 & 10000 & 10000 \\
\hline $\begin{array}{l}\text { Interest paid on } \\
\text { fixed capital @ } \\
12 \%\end{array}$ & 1200 & 1200 & 1200 & 1200 & 1200 & 1200 & 1200 & 1200 & 1200 & 1200 & 1200 & 1200 \\
\hline Total fixed cost & 11200 & 11200 & 11200 & 11200 & 11200 & 11200 & 11200 & 11200 & 11200 & 11200 & 11200 & 11200 \\
\hline \multicolumn{13}{|l|}{ Return } \\
\hline $\begin{array}{l}\text { Average yield } \\
(\mathrm{t} / \mathrm{ha})\end{array}$ & 5.9 & 5.8 & 5.3 & 4.9 & 7.6 & 8.1 & 6.3 & 5.2 & 4.8 & 4.5 & 4.3 & 4.0 \\
\hline $\begin{array}{l}\text { Selling price per } \\
\text { kg }\end{array}$ & 28.0 & 28.0 & 26.0 & 25.0 & 28.0 & 30.0 & 28.0 & 26.0 & 25.0 & 25.0 & 25.0 & 20.0 \\
\hline Gross Income & 166085 & 162781 & 137922 & 122972 & 211994 & 241692 & 176177 & 136191 & 119769 & 113021 & 106612 & 79204 \\
\hline \multicolumn{13}{|l|}{ Net Return } \\
\hline $\begin{array}{l}\text { Total cost of } \\
\text { cultivation }\end{array}$ & 43000 & 47405 & 51811 & 56216 & 55099 & 59504 & 63910 & 68315 & 72410 & 63413 & 50135 & 36019 \\
\hline Gross income & 166085 & 162781 & 137922 & 122972 & 211994 & 241692 & 176177 & 136191 & 119769 & 113021 & 106612 & 79204 \\
\hline Net return & 123086 & 115376 & 86111 & 66756 & 156895 & 182188 & 112267 & 67876 & 47358 & 49608 & 56476 & 43185 \\
\hline B:C ratio & $1: 2.86$ & $1: 2.43$ & $1: 1.66$ & $1: 1.19$ & $1: 2.85$ & $1: 3.06$ & $1: 1.76$ & $1: 0.99$ & $1: 0.65$ & $1: 0.78$ & $1: 1.13$ & $1: 1.20$ \\
\hline
\end{tabular}


Table.2 Effect of urea, poultry manure alone and in combination with Azotobacter on benefit cost ratio of kinnow mandarin cultivation

\begin{tabular}{|c|c|c|c|c|c|c|c|c|c|c|c|c|}
\hline Items of cost & $\mathbf{T}_{1}$ & $\mathbf{T}_{2}$ & $\mathbf{T}_{3}$ & $\mathbf{T}_{4}$ & $\mathbf{T}_{5}$ & $\mathbf{T}_{6}$ & $\mathbf{T}_{7}$ & $\mathbf{T}_{8}$ & $\mathbf{T}_{9}$ & $\mathbf{T}_{10}$ & $\mathbf{T}_{11}$ & $\mathbf{T}_{12}$ \\
\hline Variable cost & \multicolumn{12}{|c|}{ Amount (₹) } \\
\hline Labour & 24930 & 24930 & 24930 & 24930 & 27700 & 27700 & 27700 & 27700 & 27700 & 27700 & 24930 & 22160 \\
\hline $\begin{array}{l}\text { Cost of fertilizer } \\
\text { and manure }\end{array}$ & 3462.5 & 4044.2 & 4625.9 & 5207.6 & 11495.5 & 12077.2 & 12658.9 & 13240.6 & 13836.15 & 5803.15 & 9833.5 & 0 \\
\hline $\begin{array}{l}\text { Interest on working } \\
\text { capital @ 12\% }\end{array}$ & 3407 & 3477 & 3547 & 3617 & 4703 & 4773 & 4843 & 4913 & 4984 & 4020 & 4172 & 2659 \\
\hline Total variable cost & 31800 & 32451 & 33103 & 33754 & 43899 & 44550 & 45202 & 45853 & 46520 & 37524 & 38935 & 24819 \\
\hline \multicolumn{13}{|l|}{ Fixed cost } \\
\hline $\begin{array}{l}\text { Rent paid for leased } \\
\text { in land }\end{array}$ & 10000 & 10000 & 10000 & 10000 & 10000 & 10000 & 10000 & 10000 & 10000 & 10000 & 10000 & 10000 \\
\hline $\begin{array}{l}\text { Interest paid on } \\
\text { fixed capital @ } \\
12 \%\end{array}$ & 1200 & 1200 & 1200 & 1200 & 1200 & 1200 & 1200 & 1200 & 1200 & 1200 & 1200 & 1200 \\
\hline Total fixed cost & 11200 & 11200 & 11200 & 11200 & 11200 & 11200 & 11200 & 11200 & 11200 & 11200 & 11200 & 11200 \\
\hline \multicolumn{13}{|l|}{ Return } \\
\hline A verage yield (t/ha) & 6.1 & 6.1 & 6.2 & 5.4 & 7.9 & 7.9 & 8.6 & 6.0 & 5.3 & 4.9 & 4.3 & 3.9 \\
\hline Selling price per kg & 28 & 28 & 26 & 25 & 28 & 30 & 28 & 26 & 25 & 25 & 25 & 20 \\
\hline Gross Income & 169852 & 170616 & 160904 & 134765 & 221050 & 237935 & 241556 & 154946 & 131716 & 122534 & 107950 & 78635 \\
\hline \multicolumn{13}{|l|}{ Net return } \\
\hline $\begin{array}{l}\text { Total cost of } \\
\text { cultivation }\end{array}$ & 43000 & 43651 & 44303 & 44954 & 55099 & 55750 & 56402 & 57053 & 57720 & 48724 & 50135 & 36019 \\
\hline Gross income & 169852 & 170616 & 160904 & 134765 & 221050 & 237935 & 241556 & 154946 & 131716 & 122534 & 107950 & 78635 \\
\hline Net return & 126852 & 126965 & 116601 & 89811 & 165951 & 182185 & 185154 & 97893 & 73995 & 73811 & 57815 & 42616 \\
\hline B:C ratio & $1: 2.95$ & $1: 2.91$ & $1: 2.63$ & $1: 2.00$ & $1: 3.01$ & $1: 3.27$ & $1: 3.28$ & $1: 1.72$ & $1: 1.28$ & $1: 1.51$ & $1: 1.15$ & $1: 1.18$ \\
\hline
\end{tabular}


Table.3 Effect of urea, vermicompost alone and in combination with Azotobacter on benefit cost ratio of kinnow mandarin cultivation

\begin{tabular}{|c|c|c|c|c|c|c|c|c|c|c|c|c|}
\hline Items of cost & $\mathbf{T}_{1}$ & $\mathbf{T}_{2}$ & $\mathbf{T}_{3}$ & $\mathbf{T}_{4}$ & $\mathrm{~T}_{5}$ & $T_{6}$ & $\mathbf{T}_{7}$ & $\mathbf{T}_{8}$ & $\mathbf{T}_{9}$ & $\mathbf{T}_{10}$ & $\mathbf{T}_{11}$ & $\mathbf{T}_{12}$ \\
\hline Variable cost & \multicolumn{12}{|c|}{ Amount (₹) } \\
\hline Labour & 24930 & 24930 & 24930 & 24930 & 27700 & 27700 & 27700 & 27700 & 27700 & 27700 & 24930 & 22160 \\
\hline $\begin{array}{l}\text { Cost of fertilizer } \\
\text { and manure }\end{array}$ & 3462.5 & 13240.6 & 23018.7 & 32796.8 & 11495.5 & 21273.6 & 31051.7 & 40829.8 & 50607.9 & 42574.9 & 9833.5 & 0 \\
\hline $\begin{array}{l}\text { Interest on } \\
\text { working capital @ } \\
12 \%\end{array}$ & 3407 & 4580 & 5754 & 6927 & 4703 & 5877 & 7050 & 8224 & 9397 & 8433 & 4172 & 2659 \\
\hline Total variable cost & 31800 & 42751 & 53703 & 64654 & 43899 & 54850 & 65802 & 76753 & 87705 & 78708 & 38935 & 24819 \\
\hline \multicolumn{13}{|l|}{ Fixed cost } \\
\hline $\begin{array}{l}\text { Rent paid for } \\
\text { leased in land }\end{array}$ & 10000 & 10000 & 10000 & 10000 & 10000 & 10000 & 10000 & 10000 & 10000 & 10000 & 10000 & 10000 \\
\hline $\begin{array}{l}\text { Interest paid on } \\
\text { fixed capital @ } \\
12 \%\end{array}$ & 1200 & 1200 & 1200 & 1200 & 1200 & 1200 & 1200 & 1200 & 1200 & 1200 & 1200 & 1200 \\
\hline Total fixed cost & 11200 & 11200 & 11200 & 11200 & 11200 & 11200 & 11200 & 11200 & 11200 & 11200 & 11200 & 11200 \\
\hline \multicolumn{13}{|l|}{ Return } \\
\hline $\begin{array}{l}\text { Average yield } \\
(\mathrm{t} / \mathrm{ha})\end{array}$ & 6.0 & 6.0 & 5.5 & 5.1 & 7.8 & 8.4 & 6.7 & 5.5 & 5.0 & 4.8 & 4.3 & 3.9 \\
\hline $\begin{array}{l}\text { Selling price per } \\
\text { kg }\end{array}$ & 28 & 28 & 26 & 25 & 28 & 30 & 28 & 26 & 25 & 25 & 25 & 20 \\
\hline Gross Income & 166998 & 168736 & 143320 & 126772 & 219644 & 253018 & 186789 & 143263 & 126122 & 118910 & 107734 & 78119 \\
\hline \multicolumn{13}{|l|}{ Net return } \\
\hline $\begin{array}{l}\text { Total cost of } \\
\text { cultivation }\end{array}$ & 43000 & 53951 & 64903 & 75854 & 55099 & 66050 & 77002 & 87953 & 98905 & 89908 & 50135 & 36019 \\
\hline Gross income & 166998 & 168736 & 143320 & 126772 & 219644 & 253018 & 186789 & 143263 & 126122 & 118910 & 107734 & 78119 \\
\hline Net return & 123998 & 114784 & 78418 & 50918 & 164545 & 186968 & 109787 & 55310 & 27217 & 29002 & 57598 & 42099 \\
\hline B:C ratio & $1: 2.88$ & $1: 2.13$ & $1: 1.21$ & 1:0.67 & $1: 2.99$ & $1: 2.83$ & $1: 1.43$ & $1: 0.63$ & $1: 0.28$ & $1: 0.32$ & $1: 1.15$ & 1:1.17 \\
\hline
\end{tabular}


Int.J.Curr.Microbiol.App.Sci (2018) 7(8): 130-138

Fig.1 Comparative analysis of cost-benefit ratio of different integrated nutrient management treatments in Kinnow mandarin

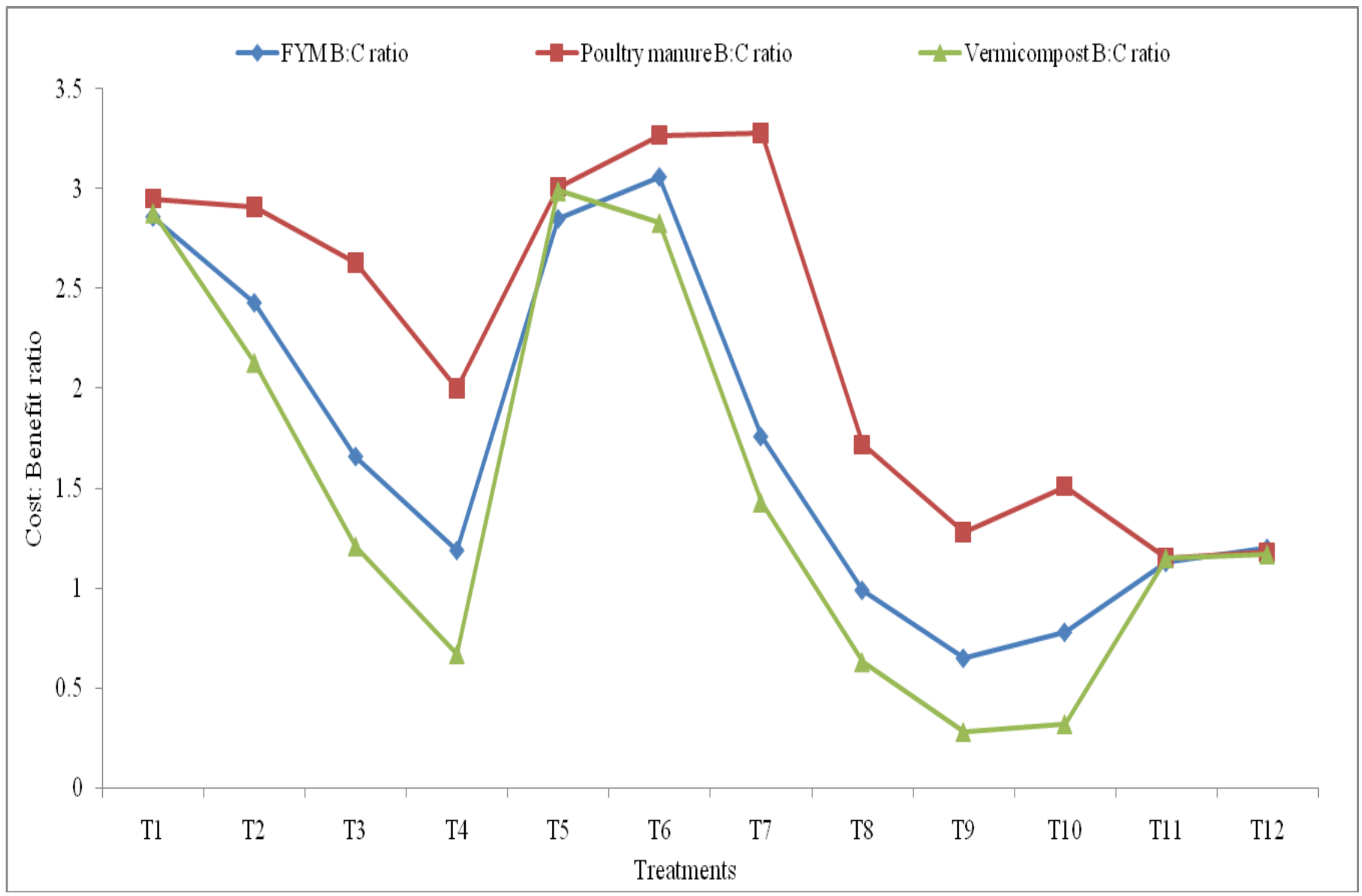


Lowest net returns (₹ 27,217.00) were obtained under control. Maximum cost benefit ratio of $(1: 2.99)$ was obtained under treatment comprising cent per cent nitrogen as urea augmented with Azotobacter $\left(\mathrm{T}_{5}\right)$ followed by benefit cost ratio of $1: 2.88$ and 1:2.83 obtained under treatment $\mathrm{T}_{1}$ (cent per cent nitrogen as urea) and $\mathrm{T}_{6}(25$ per cent nitrogen as vermicompost and 75 per cent nitrogen as urea augmented with Azotobacter). Lowest benefit cost ratio of 1:0.28 was obtained under absolute control $\left(\mathrm{T}_{12}\right)$.

Highest total cost of cultivation was observed with the application of cent per cent nitrogen as vermicompost augmented with Azotobacter followed by application of cent per cent nitrogen as vermicompost. Net returns were highest with the application of 25 per cent nitrogen as vermicompost +75 per cent nitrogen as urea augmented with Azotobacter. Maximum benefit: cost ratio was obtained with the application of cent per cent nitrogen as urea augmented with Azotobacter followed by 25 per cent nitrogen as vermicompost +75 per cent nitrogen as urea augmented with Azotobacter. Treatments comprising organic manures and biofertilizers in combination with inorganic fertilizers had higher cost of cultivation but higher yields obtained maximized the benefit resulting in higher benefit: cost ratio. Similar results were reported by Nasreen et al., (2013) in mandarin (Citrus reticulate) in mandarin with the combined application of $\mathrm{N}, \mathrm{P}, \mathrm{K}$ and $\mathrm{Mg}$ along with organic manures.

Though cost of cultivation increased with the application of farmyard along with Azotobacter, yet higher yields obtained with the integrated application of inorganic, organic and biofertilizers maximized the benefit resulting in highest cost: benefit ratio. Similar results were reported by Nasreen et al., (2013) in mandarin (Citrus reticulata) with the combined application of inorganic fertilizers and FYM.

\section{Comparative evaluation of integrated nutrient management using different organic manures}

The cost: benefit ratio of all the three experiments under study was evaluated to arrive at the best suitable integrated nutrient management option for the farmers to obtain higher profits (Fig. 1). Out of the three integrated nutrient management trials conducted, it was observed that the application of 50 per cent nitrogen source as poultry manure and 50 percent nitrogen source as urea augmented with azotobacter resulted in highest cost: benefit ratio of 1:3.28 which was statistically at par with the application of 25 percent nitrogen source as poultry manure and 75 percent nitrogen source as urea augmented with Azotobacter.

Use of integrated nutrient management practices of cultivation in Kinnow mandarin increased the cost of cultivation as compared to the application of inorganic fertilizers alone but increased yield and quality of the fruits resulted in higher net returns per ha and an increased cost benefit ratio. Use of integrated nutrient management not only results in higher net profits but also can be helpful in restoring the soil health. The study has worked out that Kinnow is a profitable commercial crop. This will help policy makers and horticultural department to encourage the orchardists for Kinnow plantation using integrated nutrient management strategies on a large scale. Integration of biofertilizers along with inorganic and organic fertilizers proved to be beneficial in terms of plant growth, yield and quality characters. The input cost of using integrated nutrient management is a bit on the higher side but it is neutralized by the substantial gains in terms of yield and quality 
of the fruits produced. Moreover, replacing nitrogen from inorganic source with an organic source also helps in enhancing the natural fertility of the soil and can be useful in the long run.

\section{Acknowledgement}

The research facilities and manpower support provided during the course of this Ph.D. research work at Sher-e-Kashmir University of Agricultural Sciences and Technology of Jammu, Main Campus, Chatha are duly acknowledged.

\section{References}

Anonymous. 2009. Economic Survey, Directorate of Economics and Statistics, Planning and Development Department, Government of Jammu and Kashmir.

Anonymous. 2015. Horticultural Statistics at a

Glance 2015. Horticulture Statistics Division Department of Agriculture, Cooperation \& Farmers Welfare Ministry of Agriculture \& Farmers
Welfare Government of India. Oxford University Press. Pp.16.

Bakshi, M., Wali, V. K., Bakshi, P., Sharma, A., Sharma, D. and Shah, R. A. (2017). Integrated nutrient management induced changes in nutrient uptake, fruit yield and quality of Kinnow mandarin. Indian Journal of Agricultural Sciences 87(3): 414-8

Gupta G S and George P S. (1974) Profitability of Nagpur santra (oranges) cultivation. Indian Journal of Agricultural Economics 24(3): 134-142.

Mamindla S, Prasad V M, Baradwaj K, Vishnu A, Sathish R and Veerendra A C. 2015. Effect of different sources of organic and inorganic plant nutrients on fruit growth, yield and quality of guava (Psidium guajava L.) cv. Allahabad Safeda. Environment and Ecology 33(1): 126-130.

Nasreen S, Ahmed R, Ullah M A and Hoque M A. 2013. Effect of N, P, K and Mg application on yield and fruit quality of mandarin (Citrus reticulata). Bangladesh Journal of Agricultural Research 38(3): 425-433.

\section{How to cite this article:}

Manish Bakshi, V.K. Wali, Akash Sharma and Vishal Raina. 2018. Economic Evaluation of Kinnow Mandarin Cultivation Using Inorganic and Organic Nutrient Sources Along with Biofertilizers. Int.J.Curr.Microbiol.App.Sci. 7(08): 130-138. doi: https://doi.org/10.20546/ijcmas.2018.708.016 